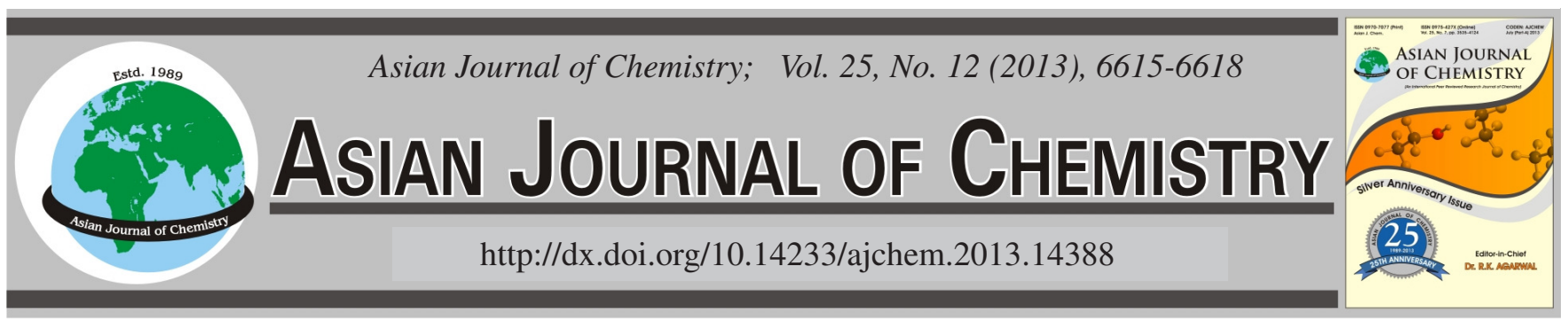

\title{
Synthesis, Crystal Structure and DNA-Binding of Lanthanum Complex with Schiff Base Derived from $o$-Vanillin and $p$-Toluidine
}

\author{
XiAO-Ju Chen ${ }^{1}$, Wei-Ji Hu ${ }^{2}$, Yi Qin ${ }^{2}$ and Guo-Liang ZhaO ${ }^{1,2, *}$
}

${ }^{1}$ College of Chemistry and Life Science, Zhejiang Normal University, Jinhua 321004, P.R. China

${ }^{2}$ Xingzhi College, Zhejiang Normal University, Jinhua 321004, P.R. China

*Corresponding author: Fax: +86 579 82282269; Tel: +86 579 82282061; E-mail: sky53@zjnu.cn

(Received: 3 August 2012;

Accepted: 22 May 2013)

AJC-13533

\begin{abstract}
A new complex $\left[\mathrm{La}\left(\mathrm{NO}_{3}\right)_{3}\left(\mathrm{C}_{2} \mathrm{H}_{5} \mathrm{OH}\right)\left(\mathrm{C}_{15} \mathrm{H}_{15} \mathrm{NO}_{2}\right)_{2}\right]$ was synthesized from lanthanum nitrate and Schiff base $\left(\mathrm{C}_{15} \mathrm{H}_{15} \mathrm{NO}_{2}\right.$, derived form $o$-vanillin and $p$-toluidine) by refluxing in ethanol. It's crystal structure was determined by single crystal X-ray diffraction method. The complex is crystallize in triclinic, space group $\mathrm{P}-1$, with $\mathrm{a}=0.79851(3) \mathrm{nm}, \mathrm{b}=1.47473(5) \mathrm{nm}, \mathrm{c}=1.63872(6) \mathrm{nm}, \alpha=73.546(2)^{\circ}, \beta=$ $86.769(2)^{\circ}, \gamma=79.767(2)^{\circ}, V=1.82123(1) \mathrm{nm}^{3}, \mathrm{Z}=2, \mathrm{M}_{\mathrm{r}}=852.56, \mathrm{~F}(000)=1862, \mathrm{Dc}=1.555 \mathrm{~g} \mathrm{~cm}^{-3}, \mu\left(\mathrm{M}_{0} \mathrm{~K}_{\alpha}\right)=1.056 \mathrm{~mm}^{-1}$. It turned out that six oxygen atoms from three nirtate anions, one oxygen atom in ethanol and two phenolate oxygen atoms from two Schiff base ligands coordinate to $\mathrm{La}(\mathrm{III})$, forming a 9-coordination distorted monocapped square prism geometry. In addition, DNA-binding of the complex was studied by EtBr fluoescent probe and the results show that the complex interact with DNA by intercalative mode. CCDC:878971.
\end{abstract}

Key Words: Schiff base, $o$-Vanillin, $p$-Toluidine, Lanthanum complex, Crystal structure, DNA-binding.

\section{INTRODUCTION}

It is well know that Schiff bases are important in multiple fields such as chemistry and biochemistry owing to their biological activities ${ }^{1,2}$. Schiff bases complexes prepared by ligands from substituted $o$-vanillin have been absorbed considerable attention in the past decades due to the intriguing biological activities $^{3-5}$. DNA-binding is the critical step for DNA activity. To design effective chemotherapeutic agents and better anticancer drugs, it is essential to explore the interactions of metal complexes with DNA. Great effort has been made to metal complexes binding to DNA through an intercalation mode with their structures containing fully planar intercalating into the adjacent base pairs of $\mathrm{DNA}^{6-10}$. In addition, lanthanide ions have high and variable coordination numbers and flexible coordination geometry ${ }^{11,12}$. Studies on the interaction of lanthanide metal complexes with DNA have been an active field of research. Interested in this field, a new Schiff base complex, $\left[\mathrm{La}\left(\mathrm{NO}_{3}\right)_{3}\left(\mathrm{C}_{2} \mathrm{H}_{5} \mathrm{OH}\right)\left(\mathrm{C}_{15} \mathrm{H}_{15} \mathrm{NO}_{2}\right)_{2}\right]$ was synthesized and characterized. The DNA-binding experiment of the complex suggest that the complex bind to DNA in an intercalation mode.

\section{EXPERIMENTAL}

All reagents were of analytical grade quality and were used without further purification. The FTIR spectra were obtained from $\mathrm{KBr}$ pellets in the range $4000-400 \mathrm{~cm}^{-1}$ with a Nicolet NEXUS 670 FTIR spectrometer. Thermal analyses were carried out using Mettler-Toledo TGA/SDTA $851^{\mathrm{e}}$ thermal analyzer at a heating rate of $10^{\circ} \mathrm{C} \mathrm{min}^{-1}$ from 30 to $800{ }^{\circ} \mathrm{C}$ in air atmosphere. Fluorescence spectra were recorded on a 970CRT spectrofluorophotometer. Diffraction data were collected at 296(2)K on a Bruker APEXII CCD diffractometer with graphite monochromated $\mathrm{M}_{0} \mathrm{~K}_{\alpha}$ radiation $(\lambda=0.071073 \mathrm{~nm})$.

Synthesis of the complex: A solution of lanthanuml(III) nitrate hexahydrate salt $(0.5 \mathrm{mmol})$ in ethanol $(10 \mathrm{~mL})$ was added to a boiling solution of the Schiff base $(1 \mathrm{mmol})$ in ethanol $(30 \mathrm{~mL})$. The mixture was gently heated on a water bath for $2 \mathrm{~h}$ and then left to stand overnight. The complex that crystallized out of the reaction mixture were filtered off washed with ethanol and dried in a desiccator over anhydrous silica gel. Yield $80 \%$ based on metal. Anal. calcd. (\%) for $\mathrm{C}_{32} \mathrm{H}_{36} \mathrm{~N}_{5} \mathrm{O}_{14} \mathrm{La}: \mathrm{C}, 45.16 ; \mathrm{H}, 4.11, \mathrm{~N}, 8.15$. Found (\%): $\mathrm{C}$, 45.04; H, 4.11; N, 8.21. IR (KBr, $\left.v_{\max }, \mathrm{cm}^{-1}\right): 3441(\mathrm{~m}), 3414$ (m), 3044(w), 2946 (w), 2843(w), 1637 (s), 1549 (s), 1502(s), 1384 (s), 1305(s), 1233(s), 1032 (s), 823(w), 731(w), 491(m).

DNA-binding experiments: $2 \mathrm{~mL}$ EB solution $(100 \mu \mathrm{g}$ $\left.\mathrm{mL}^{-1}\right)$ and $1.0 \mathrm{~mL}$ DNA solution $\left(200 \mu \mathrm{g} \mathrm{mL}^{-1}\right)$ were added to $10 \mathrm{~mL}$ colourimetric tube, the DNA-binding ability of the complex to EB-DNA were studied in $2 \mathrm{~mL}$ tris $-\mathrm{HCl} / \mathrm{NaCl}$ buffer $(\mathrm{pH}=7.4)$. After standing for $2 \mathrm{~h}$, gradually with adding a certain amount of the complex solutions to the mixture and 
reacting for $12 \mathrm{~h}$ at $4{ }^{\circ} \mathrm{C}$. The excitement wavelength was aroused at $251 \mathrm{~nm}$ and each sample solution was scanned in the range $520-700 \mathrm{~nm}$.

Crystal structure determination: A single crystal of the title complex with dimentions of $0.202 \mathrm{~mm} \times 0.192 \mathrm{~mm} \times 0.168$ $\mathrm{mm}$ was selected and mounted on a glass fiber and collected diffraction data on a Bruker Smart APEX II CCD diffractometer with graphite monochromated $\mathrm{M}_{0} \mathrm{~K}_{\alpha}$ radiation $(\lambda=0.071073$ $\mathrm{nm})$. Structure was solved by direct methods using SHELXS$97^{13}$ and refined on the $\mathrm{F}^{2}$ by full-matrix least-square method with SHELXL-97 ${ }^{14}$. All non-hydrogen atoms were refined anisotropically. Hydrogen atoms were placed in geometrically calculated positions and refined by using a riding mode. Experimental details for X-ray data collection are presented in Table-1 and the selected bond lengths and angles are listed in Table-2. CCDC No. 878971 of 1 contains the supplementary crystallographic data for this paper. These data can be obtained free of charge from the Cambridge crystallographic data centre.

TABLE-1

CRYSTALLOGRAPHIC DATA FOR THE COMPLEX

\begin{tabular}{ll}
\hline Empirical formula & $\mathrm{C}_{32} \mathrm{H}_{36} \mathrm{~N}_{5} \mathrm{O}_{14} \mathrm{La}$ \\
Formula weight & 852.56 \\
Temperature / K & $296(2)$ \\
Wavelength / $\AA$ & 0.71073 \\
Crystal system, & Triclinic \\
Space group & $\mathrm{P}-1$ \\
$\mathrm{a}(\mathrm{nm})$ & $0.79851(3)$ \\
$\mathrm{b}(\mathrm{nm})$ & $1.47473(5)$ \\
$\mathrm{c}(\mathrm{nm})$ & $1.63872(6)$ \\
$\alpha\left({ }^{\circ}\right)$ & $73.546(2)$ \\
$\beta\left({ }^{\circ}\right)$ & $86.769(2)$ \\
$\gamma\left({ }^{\circ}\right)$ & $79.767(2)$ \\
$\left.\mathrm{V}(\mathrm{nm})^{3}\right)$ & $1.82123(1)$ \\
$\mathrm{Z}$ & 2 \\
Dc $(\mathrm{g}$ cm & \\
Absorption coefficient $\left(\mathrm{mm}^{-1}\right)$ & 1.555 \\
$\mathrm{~F}(000)$ & 1.246 \\
Crystal size (mm) & 862 \\
Theta range for data collection $\left({ }^{\circ}\right)$ & $0.202 \times 0.192 \times 0.168$ \\
Limiting indices & 1.66 to 27.52 \\
& $-10<=\mathrm{h}<=10,-19<=\mathrm{k}<=19,-$ \\
Reflections collected (unique) & $20<=1<=21$ \\
Completeness to $\theta=27.52(\%)$ & $29358 / 8305[\mathrm{R}($ int $)=0.0268]$ \\
Max. and min. transmission & 98.9 \\
Refinement method & 0.809 and 0.779 \\
Data/restraints/parameters & Full-matrix least-squares on $\mathrm{F}^{2}$ \\
Goodness-of-fit on $\mathrm{F}^{2}$ & $8305 / 600 / 465$ \\
Final $R$ indices [I $>2 \sigma(\mathrm{I})]$ & 1.009 \\
$\mathrm{R}$ indices (all data) & $\mathrm{R}_{1}=0.0308, \mathrm{wR}_{2}=0.0842$ \\
Largest diff. peak and hole $\left(\mathrm{e} \mathrm{nm}^{-3}\right)$ & 576 and -534 \\
\hline & \\
\hline
\end{tabular}

\section{RESULTS AND DISCUSSION}

IR spectrum: The broad absorption band at $3414 \mathrm{~cm}^{-1}$ is attributed to the hydroxyl group of the free ligand. The $\mathrm{H}$ atoms of the Schiff base ligand migrate to the azomethine $\mathrm{N}$ atom via $\mathrm{N}-\mathrm{H} \cdots \mathrm{O}$ intramolecular hydrogen bonding and with absorption at $3441 \mathrm{~cm}^{-1}$, showing coordination of oxygen atom of the phenolic hydroxyl with the central La(III) ion as reported in the literature ${ }^{15}$. The $\mathrm{C}-\mathrm{O}(\mathrm{Ph}-\mathrm{OH})$ stretching vibration shift from $1257 \mathrm{~cm}^{-1}$ to $1233 \mathrm{~cm}$ also supports the coordination of oxygen atoms, which indicating that coordination
TABLE 2

SELECTED BOND LENGTHS (nm) AND ANGLES $\left(^{\circ}\right.$ )

\begin{tabular}{lclc}
\hline Bond & Length & Bond & Length \\
\hline $\mathrm{La}(1)-\mathrm{O}(6)$ & $0.2651(3)$ & $\mathrm{La}(1)-\mathrm{O}(13)$ & $0.2481(2)$ \\
$\mathrm{La}(1)-\mathrm{O}(11)$ & $0.2432(2)$ & $\mathrm{La}(1)-\mathrm{O}(14)$ & $0.2530(2)$ \\
$\mathrm{La}(1)-\mathrm{O}(5)$ & $0.2669(3)$ & $\mathrm{La}(1)-\mathrm{O}(7)$ & $0.2648(6)$ \\
$\mathrm{La}(1)-\mathrm{O}(9)$ & $0.2708(6)$ & $\mathrm{La}(1)-\mathrm{O}\left(7^{\prime}\right)$ & $0.2710(8)$ \\
$\mathrm{La}(1)-\mathrm{O}(2)$ & $0.2777(7)$ & $\mathrm{La}(1)-\mathrm{O}\left(2^{\prime}\right)$ & $0.2802(8)$ \\
$\mathrm{La}(1)-\mathrm{O}(1)$ & $0.2586(6)$ & $\mathrm{La}(1)-\mathrm{O}\left(1^{\prime}\right)$ & $0.2577(6)$ \\
$\mathrm{La}(1)-\mathrm{O}(9)$ & $0.2769(7)$ & & \\
\hline $\mathrm{Angle}$ & $\left({ }^{\circ}\right)$ & $\mathrm{Angle}$ & $\left({ }^{\circ}\right)$ \\
\hline $\mathrm{O}(11)-\mathrm{La}(1)-\mathrm{O}(13)$ & $131.36(80)$ & $\mathrm{O}(11)-\mathrm{La}(1)-\mathrm{O}(14)$ & $79.67(80)$ \\
$\mathrm{O}(11)-\mathrm{La}(1)-\mathrm{O}(1)$ & $118.26(14)$ & $\mathrm{O}(13)-\mathrm{La}(1)-\mathrm{O}(14)$ & $72.30(90)$ \\
$\mathrm{O}(14)-\mathrm{La}(1)-\mathrm{O}(1)$ & $81.46(15)$ & $\mathrm{O}(13)-\mathrm{La}(1)-\mathrm{O}(10)$ & $96.17(15)$ \\
$\mathrm{O}(11)-\mathrm{La}(1)-\mathrm{O}(7)$ & $110.70(15)$ & $\mathrm{O}(13)-\mathrm{La}(1)-\mathrm{O}(7)$ & $113.38(14)$ \\
$\mathrm{O}(14)-\mathrm{La}(1)-\mathrm{O}(7)$ & $150.26(16)$ & $\mathrm{O}(11)-\mathrm{La}(1)-\mathrm{O}(6)$ & $64.71(80)$ \\
$\mathrm{O}(1)-\mathrm{La}(1)-\mathrm{O}(7)$ & $69.0(20)$ & $\mathrm{O}(14)-\mathrm{La}(1)-\mathrm{O}(6)$ & $133.59(90)$ \\
$\mathrm{O}(13)-\mathrm{La}(1)-\mathrm{O}(6)$ & $109.50(80)$ & $\mathrm{O}(1)-\mathrm{La}(1)-\mathrm{O}(6)$ & $140.97(16)$ \\
$\mathrm{O}(7)-\mathrm{La}(1)-\mathrm{O}(6)$ & $73.88(16)$ & $\mathrm{O}(11)-\mathrm{La}(1)-\mathrm{O}(5)$ & $109.61(80)$ \\
$\mathrm{O}(13)-\mathrm{La}(1)-\mathrm{O}(5)$ & $69.61(80)$ & $\mathrm{O}(14)-\mathrm{La}(1)-\mathrm{O}(5)$ & $135.48(10)$ \\
$\mathrm{O}(7)-\mathrm{La}(1)-\mathrm{O}(5)$ & $69.00(15)$ & $\mathrm{O}(1)-\mathrm{La}(1)-\mathrm{O}(5)$ & $124.45(13)$ \\
$\mathrm{O}(11)-\mathrm{La}(1)-\mathrm{O}(9)$ & $67.72(14)$ & $\mathrm{O}(6)-\mathrm{La}(1)-\mathrm{O}(5)$ & $47.12(80)$ \\
$\mathrm{O}(14)-\mathrm{La}(1)-\mathrm{O}(9)$ & $123.99(14)$ & $\mathrm{O}(13)-\mathrm{La}(1)-\mathrm{O}(9)$ & $159.58(14)$ \\
$\mathrm{O}(1)-\mathrm{La}(1)-\mathrm{O}(9)$ & $76.2(20)$ & $\mathrm{O}(7)-\mathrm{La}(1)-\mathrm{O}(9)$ & $46.24(18)$ \\
$\mathrm{O}(6)-\mathrm{La}(1)-\mathrm{O}(9)$ & $69.52(15)$ & $\mathrm{O}(5)-\mathrm{La}(1)-\mathrm{O}(9)$ & $98.80(14)$ \\
$\mathrm{O}(14)-\mathrm{La}(1)-\mathrm{O}(2)$ & $98.23(17)$ & $\mathrm{O}(11)-\mathrm{La}(1)-\mathrm{O}(2)$ & $164.87(17)$ \\
$\mathrm{O}(1)-\mathrm{La}(1)-\mathrm{O}(2)$ & $46.8(20)$ & $\mathrm{O}(13)-\mathrm{La}(1)-\mathrm{O}(2)$ & $60.57(16)$ \\
$\mathrm{O}(6)-\mathrm{La}(1)-\mathrm{O}(2)$ & $123.72(17)$ & $\mathrm{O}(7)-\mathrm{La}(1)-\mathrm{O}(2)$ & $64.3(20)$ \\
$\mathrm{O}(9)-\mathrm{La}(1)-\mathrm{O}(2)$ & $102.2(20)$ & $\mathrm{O}(5)-\mathrm{La}(1)-\mathrm{O}(2)$ & $82.49(17)$ \\
\hline & & & \\
& & & \\
\hline
\end{tabular}

bonds were formed between the metal ion and the oxygen atoms of the phenol hydroxy $1^{16}$. The presence of broad band at $3044 \mathrm{~cm}^{-1}$ indicating the hydrogen bonds of the $\mathrm{N}-\mathrm{H} \cdots \mathrm{O}$. The five absorption bands of 1502, 1305, 1032, 823 and 731 $\mathrm{cm}^{-1}$ can be assigned to the vibrations of the bidentate $\mathrm{NO}_{3}^{-}$. The feature at $1637 \mathrm{~cm}^{-1}$ may be assigned to the $v(\mathrm{C}=\mathrm{N})$ stretching in the Schiff base ligand. A new band at $491 \mathrm{~cm}^{-1}$ attributed to La-O stretching vibration also appears.

Description of the structure: The crystal structure of the complex is shown in Fig. 1. Four O atoms $(\mathrm{O} 1, \mathrm{O} 2, \mathrm{O} 7$, O9) in two nitrate anions are disordered over two sites (all assigned in a 50:50 ratio), in order to make it clear, we don't show it in Fig. 1. Nine $\mathrm{O}$ atoms coordinate to $\mathrm{La}(\mathrm{III})$ ion, six of which come from three nitrate radical anions, one comes from ethanol and the other two come from the Schiff base ligands (HL). The Schiff base HL ligand coordinate to La(III) ion in monodentate mode, using $\mathrm{O}$ atoms from deprotonated phenolic hydroxyl groups. The bond lengths of La-O (phenolic) are 0.2432(2) and 0.2481(2) nm, which are shorter than La-O (methoxy) (0.2811(2) and 0.3001(3) nm for La-O12 and La-O10), so we know that there exist a weak interaction between $\mathrm{La}(\mathrm{III})$ and the $\mathrm{O} 12, \mathrm{O} 10$ atoms. The nitrate anions coordinate to $\mathrm{La}$ (III) with the distances ranging from $0.2577(6)$ to $0.2777(7) \mathrm{nm}$, which are intermediate between the La-O (phenolic) and the La-O (methoxy) bond lengths. The La-O (methoxy) bond length is only slightly longer than the La-O (phenolic), which are similar with the reported complexe ${ }^{15}$.

The coordination geometry of $\mathrm{La}(\mathrm{III})$ can be described as a distorted monocapped square prism geometry (Fig. 2), Atoms O2, O6, $\mathrm{O} 7$ and $\mathrm{O} 13$ form a similar square plane with a mean deviation of $0.1321 \mathrm{~nm}$. The other square plane is defined by $\mathrm{O} 1, \mathrm{O} 9, \mathrm{O} 11$ and $\mathrm{O} 14$ and its mean deviation from 
plane is $0.0182 \mathrm{~nm}$. The dihedral angle is $15.140(86)^{\circ}$ between the two plane. Atom $\mathrm{O5}$ is located as the cap to complete the coordination environment of the La center.

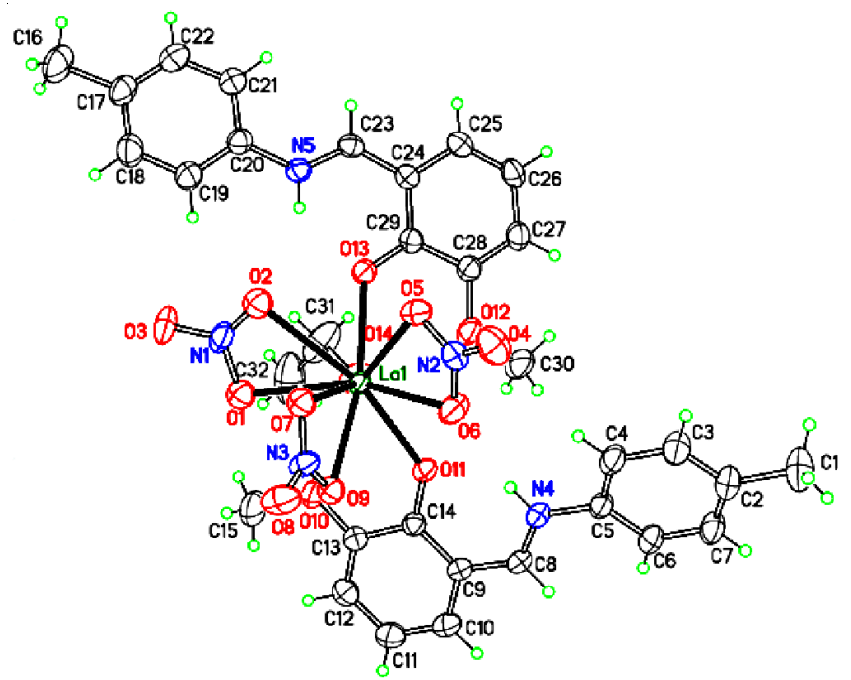

Fig. 1. Molecular structure of the title complex with thermal ellipsoids shown at the $30 \%$ level

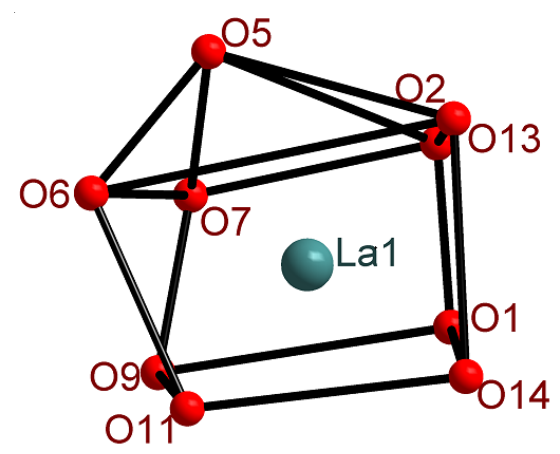

Fig. 2. Coordinate of the title complex

The hydrogen bonds and $\pi \cdots \pi$ weak non-covalent interactions tend to stability to the crystal structure. The hydrogen bonds are listed in Table- 3 and the stacking plot of this complex is shown in Fig. 3. In each Schiff base ligand, the proton of phenolic hydroxyl group is transferred to the imine $\mathrm{N}$ atom, which is involved in the formation of intramolecular hydrogen bonds.

TABLE-3

HYDROGEN BOND GEOMETRY FOR TITLE COMPLEX $\left(\mathrm{nm},{ }^{\circ}\right)$

\begin{tabular}{|c|c|c|c|c|}
\hline $\mathrm{D}-\mathrm{H} \cdots \mathrm{A}$ & $\mathrm{D}-\mathrm{H}$ & $\mathrm{H} \cdots \mathrm{A}$ & $\mathrm{D} \cdots \mathrm{A}$ & $\mathrm{D}-\mathrm{H} \cdots \mathrm{A}$ \\
\hline N5-H5A $\cdots \mathrm{O} 13$ & 0.086 & 0.198 & $2.648(3)$ & 134.2 \\
\hline $\mathrm{N} 4-\mathrm{H} 4 \mathrm{~A} \cdots \mathrm{O} 11$ & 0.086 & 0.204 & $2.687(3)$ & 131.2 \\
\hline
\end{tabular}

Thermogravimetric analysis: The TG curve of complex 1 is shown in Fig. 4. The first stage decomposition temperature is in the range of $220-300{ }^{\circ} \mathrm{C}$, with a mass loss of $27.09 \%$, which corresponds to the elimination of one $\mathrm{CH}_{3} \mathrm{CH}_{2} \mathrm{OH}$ and three $\mathrm{NO}_{3}^{-}$(calcd. $27.39 \%$ ). In the second to third stage of decomposition in the $300{ }^{\circ} \mathrm{C}-735^{\circ} \mathrm{C}$ temperature range, the Schiff base ligands are lost, with a mass loss of $53.81 \%$ (calcd. $53.49 \%)$. The final product is the metal oxide $\mathrm{La}_{2} \mathrm{O}_{3}(19.10$ $\%$, calcd.19.12\%). The result is in good accordance with the composition of the complex.

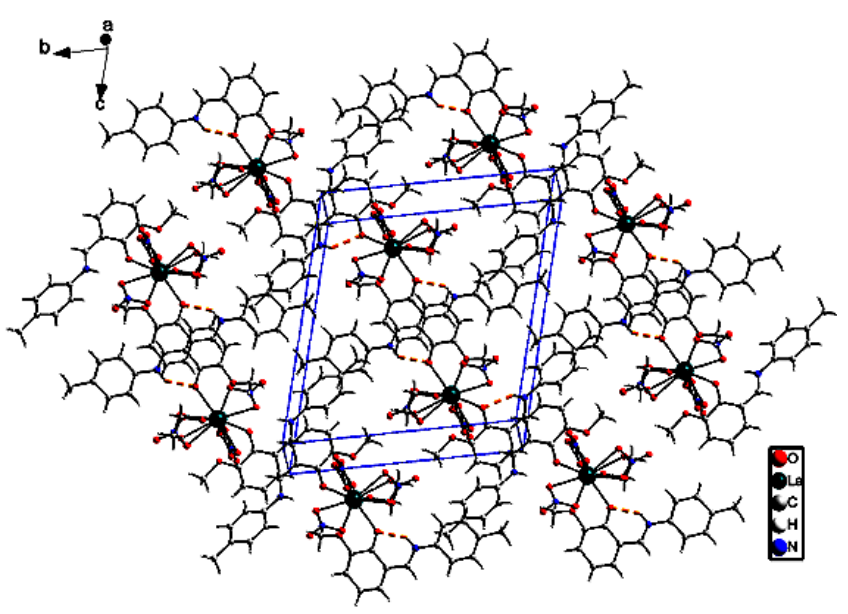

Fig. 3. Packing plot of the title complex

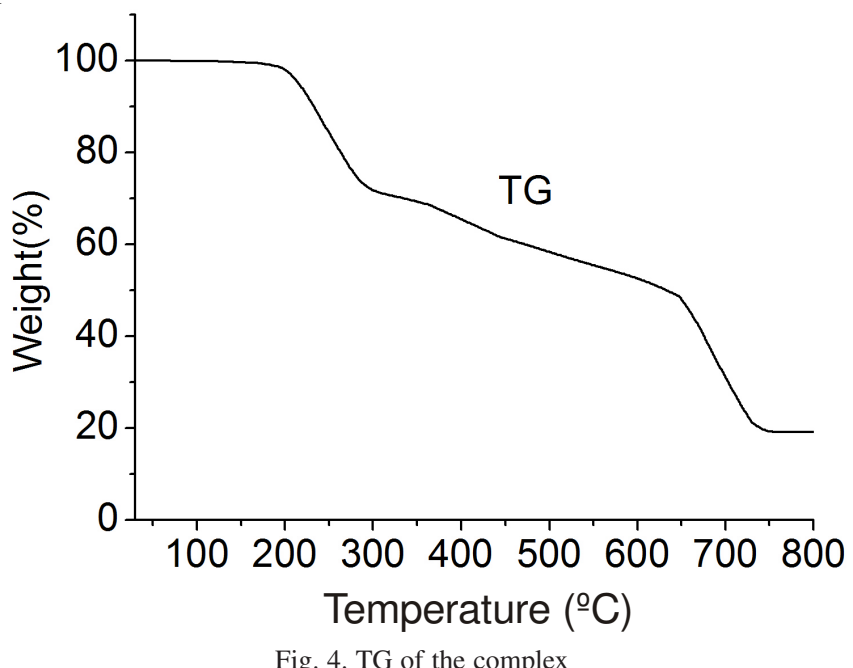

Fluorescence quenching studies: Fig. 5 shows that the effects of the complex on the fluorescence spectra of EB-DNA system. Upon addition of the tested complex, the emission intensity at $592 \mathrm{~nm}$ of EB-DNA system decreased in different degrees, indicating that the complex competes with EB to bind with DNA. The fluorescence quenching constant $\left(\mathrm{K}_{\mathrm{sq}}\right)$ of the

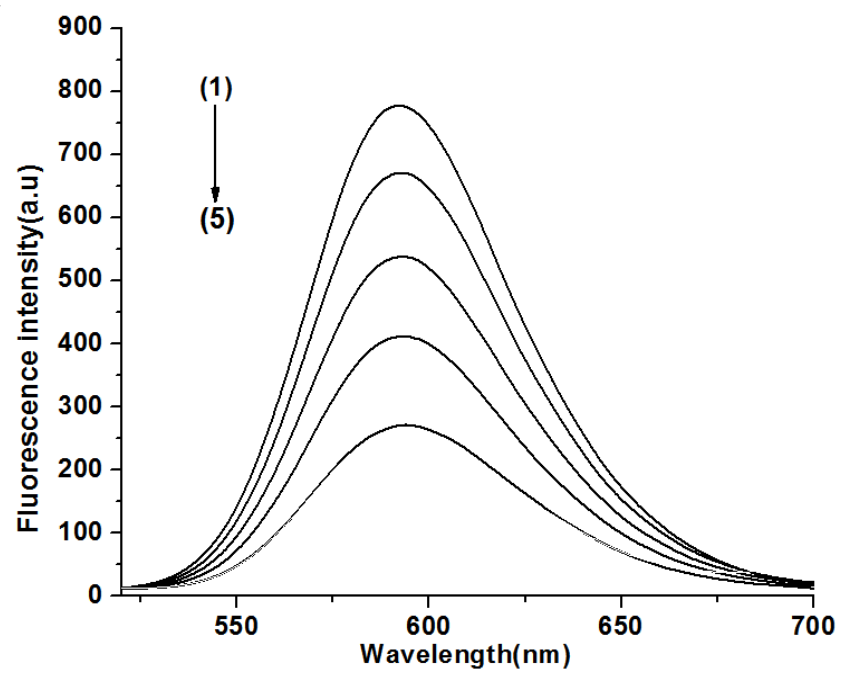

Fig. 5. Effects of the complex on the fluorescence spectra of EB-DNA system; $\left(r_{1}=0 ; r_{2}=0.059 ; r_{3}=0.118 ; r_{4}=0.177 ; r_{5}=0.236\right)$ 
title complex is 5.49. The quenching plots illustrate that the quenching of EB-bound EB-DNA system by the complex agree well with the Stern-Volmer equation ${ }^{16}: \mathrm{I}_{0} / \mathrm{I}=1+\mathrm{Ksqr}$. It indicating that interaction of the complex with DNA was strong and could release some free EB from EB-DNA ${ }^{17}$, which may be due to the five chelating rings created by the ligand and metal. These rings strong the planarity of Schiff base HL ligand, at the same time the Schiff base HL ligand possessing a great conjugated structure can effectively improve the DNAbinding affinity of the complex. so it is easy for the complex to insert to the base of DNA molecule to compete with the combination of EB-DNA sites.

\section{REFERENCES}

1. J.E. Kovacic, Spectrochim. Acta A, 23, 183 (1967).

2. R. Atkins, G. Brewer and E. Kokot, G.M. Mockler and E. Sinn, Inorg. Chem., 24, 127 (1985).

3. G.L. Zhao, P.H. Zhang and Y.L. Feng, Chin. J. Inorg. Chem., 21, 421 (2005).
4. R.C. Burrows and J.C. Bailar, J. Am. Chem. Soc., 88, 4150 (1966)

5. C. Metcalfe and J.A. Thomas, Chem. Soc. Rev., 32, 215 (2003).

6. K.K. Patel, E.A. Plummer, M. Darwish, A. Rodger and M.J. Hannon, J. Inorg. Biochem., 91, 220 (2002).

7. N. Shahabadi, S. Kashanian and F. Darabi, Eur. J. Med. Chem., 45, 4239 (2010).

8. C. Stinner, M.D. Wightman, S.O. Kelley, M.G. Hill and J.K. Barton, Inorg. Chem., 40, 5245 (2001).

9. X. Li, Y.T. Li, Z.Y. Wu, Y.-J. Zheng and C.-W. Yan, Inorg. Chim. Acta, 385, 150 (2012).

10. P.U. Maheswari and M. Palaniandavar, Inorg. Chim. Acta, 354, 901 (2004).

11. H.B. Zhang, N. Li, C.B. Tian, T.F. Liu, F.L. Du, P. Lin, Z.H. Li and S.-W. Du, Cryst. Growth Des., 12, 670 (2012).

12. H.B. Zhang, Y. Peng, X.C. Shan, C.-B. Tian, P. Lin and S.-W. Du, Inorg. Chem. Comm., 14, 1165 (2011).

13. G.M. Sheldrick, SHELXS-97. Program for the Solution of Crystal Structures. University of Götingen, Germany (1997).

14. G.M. Sheldrick, SHELXL-97. Program for the Refinement of Crystal Structures. University of Götingen, Germany(1997).

15. J.L. Liu, H.T. Cai and G.L. Zhao, Acta Cryst. E., E66, m1332 (2010).

16. J.R. Lakowicz and G. Weber, Biochemistry, 12, 4161 (1973).

17. N. Wang, Q.-Y. Lin, J. Feng, Y.-L. Zhao, Y.-J. Wang and S.-K. Li, Inorg. Chim. Acta, 363, 3399 (2010). 